IOSR Journal of Pharmacy

ISSN: 2250-3013, www.iosrphr.org

||| Volume 2 Issue 5 ||| Sep-Oct. 2012 ||| PP.07-11

\title{
Localization of interleukin-2 in goat ovary
}

\author{
Rajneesh Sharma and Esha Gandhi \\ Department of Zoology, Kurukshetra University, Kurukshetra -136119 India. \\ Home adderess: ajay kutir 2034/7D Faridabad, Haryana-121006 (India).
}

\begin{abstract}
Distribution and relative frequencies of interleukin-2 in normal cycling goat ovaries were studied to explain local immunological defense mechanisms. IL-2 was observed in primordial, primary, secondary and antral follicles. Interleukins are known best for their involvement in the immune system and their role during inflammation. In the ovary, ovarian follicle is a site of inflammatory reaction. Thus ovarian cells could represent sources and targets of interleukins. Objective: To explore this, we have examined the localisation of interleukin-2 in goat ovarian follicles. Study design: Mature goat ovaries were collected from slaughter houses and brought to laboratory at $4^{\circ} \mathrm{C}$ in normal saline. Mouse monoclonal antibody (mAb) was used at a 1:1000 dilution, Biotinylated goat anti polyvalent IgG was used as secondary antibody (TP-015-BN). A streptavidin alkaline phosphatase (lab vision, corporation, TP015-AP) method was applied to detect IL-2+ cells. The specific color reaction was developed with napthol phosphate (fast red tablets). Results: $I L-2^{+}$cells were found in small numbers in developing follicles and newly formed corpora lutea, while atretic follicles and regressing corpora lutea contained these cells in abundance. Conclusion: The frequency of IL-2+ cells was higher in the atretic follicles of all stages. This suggests that interleukin 2 play an important role in follicular atresia rather than follicular growth in normal cycling ovaries.
\end{abstract}

Keywords—goat, ovary, interleukin-2.

\section{INTRODUCTION}

Cytokines are small proteins $(15 \pm 60 \mathrm{KDa})$ that act locally through specific cell surface receptors to coordinate interactions of the immune system and surrounding tissues. Macrophages secretes a diverse repertoire of cytokines including IL-1, IL-2, IL-6, IL-10, IL-12, interferon- $\alpha$, tumor necrosis factor- $\alpha$ and granulocyte macrophage-colony stimulating factors. These cytokines have been identified in the ovaries of many species and are known to impact many aspects of ovarian function $[1,2,3]$ including follicle growth and differentiation, cell apoptosis, ovulation, and corpus luteum formation and regression [4,5,6,7]. Therefore, it can be postulated that interaction between the endocrine and cytokine system play an important role in the regulation of follicular development and atresia [8,9]. Interleukins are known best for their involvement in the immune system and their role during inflammation. Among all of the interleukins, interleukin-2 which is also known as T-cell growth factor was first described as a lymphokine capable of promoting the long term in vitro proliferation of activated $\mathrm{T}$ cell [10]. It has also been shown to modulate many other immunologic effects on cell including cytotoxic T-cells [11,12], natural killer cells [13,14], activated B-cells [15] and lymphokine activated killer cells $[16,17]$. Although IL-2 has been recognized as a well known cytokine but very little is known about its physiological significance in the ovary. As a cytokine, it has the ability to communicate with the neighbouring cells, but no information is available on its localization in the ovary.

\subsection{Immunohistochemistry}

\section{MATERIALS AND METHODS}

Chemicals and reagents: Mature goat ovaries were collected from slaughter houses of Chandigarh and brought to laboratory at $4{ }^{\circ} \mathrm{C}$ in normal saline. Mouse monoclonal antibody $(\mathrm{mAb})$ to T-cells subset helper/induced cell IL-2 was used at a 1:1000 dilution, Biotinylated goat anti polyvalent IgG was used as secondary antibody (TP-015-BN). A streptavidin alkaline phosphatase (lab vision, corporation, TP-015-AP) method was applied to detect T lymphocytes. The specific color reaction was developed with napthol phosphate (fast red tablets).

Goat ovaries were brought to lab at $4^{\circ} \mathrm{C}$ in normal saline and fixed in $4 \%$ formalin for $24 \mathrm{hrs}$. After dehydration tissue was embedded in paraffin wax. Section was cut at $5 \mu \mathrm{m}$ thick. After deparafinisation, sections were dehydrated in graded ethanol series. Then it was rinsed 4 times in PBS 
for 10 minutes. There after the sections were incubated with ultra $\mathrm{V}$ block for 5 minutes to block non specific background staining. Then sections were incubated in primary antibody for overnight and one slide was kept for positive control to examine the difference. Then sections were washed 4 times in PBS for 10 minutes and incubated for 45 minutes with secondary antibody. Sections were rinsed four times in buffer. Then sections were incubated with streptavidin alkaline phosphatase for 10 minutes at room temperature. Then sections were washed 4 times in buffer. Then sections were stained with fast red tablets dissolved in naphthol phosphate substrate for 10-20 minutes. Then sections were counter stained with hematoxylene.

Negative sign in table shows-not observed (-), weakly-1-20\% of cells (+), mild-20-40\% of cells $(++)$, moderate-40-60\% of cells $(+++)$, strong-60-80\% of cells $(++++)$, intense- $80-100 \%$ of cells $(+++++)$ indicating the relative intensities of the signals average for the specimens during follicular development.

\subsection{IL-2 ${ }^{+}$Cells}

\section{RESULTS}

Results of present study indicate that the goat ovary contains immunologically dynamic cells which vary in nature and concentration depending upon the type of ovarian structure and the stage of development or atresia. The transverse sections of goat ovary were examined to study ovarian follicles and corpora lutea through many stages of development and regression. IL $-2^{+}$cells were found in small numbers in developing follicles and newly formed corpora lutea, while atretic follicles and regressing corpora lutea contained these cells in abundance.

The distribution of IL- $2^{+}$cells was observed in the goat ovarian components. IL- 2 was studied in the oocyte of primordial follicle but granulosa cells remained unstained. In primary follicles, intensity of IL-2 in granulosa cells was weak to mild. IL-2 was localized in the oocyte and theca cells during secondary and dominant follicles their intensity was moderate in primordial and primary whereas strong to intense in dominant follicles. In the oocyte, cytoplasm and plasma membrane stained strongly, along with the germinal vesicle of the oocyte. IL-2 was not detected in cumulus cells of healthy follicles. It was detected in both granulosa and theca layer of dominant follicles and the percentage of IL-2 $2^{+}$granulosa cells were slightly higher than that of IL-2 $2^{+}$thecal cells.

Frequency of IL-2 was increased in atretic follicles both in granulosa cells and thecal cells in the dominant atretic follicles. In atretic follicles, number of $\mathrm{IL}-2^{+}$cell type increased from primary to large sized follicles as compared to their counterpart normal developing follicles. The number of percentage in granulosa, theca, cumulus cells and oocyte were increased from 23.36, 41.84, 69.55 and 15.25 to $72.08,68.57,97.07$ and 47.23 respectively in normal large antral follicles and atretic antral follicles. The frequency of IL-2 ${ }^{+}$cells was higher in the atretic follicles at all stages.

Strong reactivity for IL-2 was also observed in stroma but negative inside the blood vessels. IL-2 cells were also observed from early to late stages of corpus luteum development and regression with different intensity of stain. The maximum reactivity was observed in atretic dominant follicles.

The changes in the distribution of T-cells in the goat corpus luteum during corpus luteum regression were studied. Negligible reaction for T-cells was seen in the healthy corpus luteum, but abundant $\mathrm{T}$-cells accumulated in the corpus luteum at the regression stage.

Furthermore, we examined the changes in the localization of IL-2 in corpus luteum during corpus luteum regression. No observable difference in the localization of IL-2 was seen in any corpus luteum. Scattered moderate positive staining for IL-2 observed in all corpus luteum. 

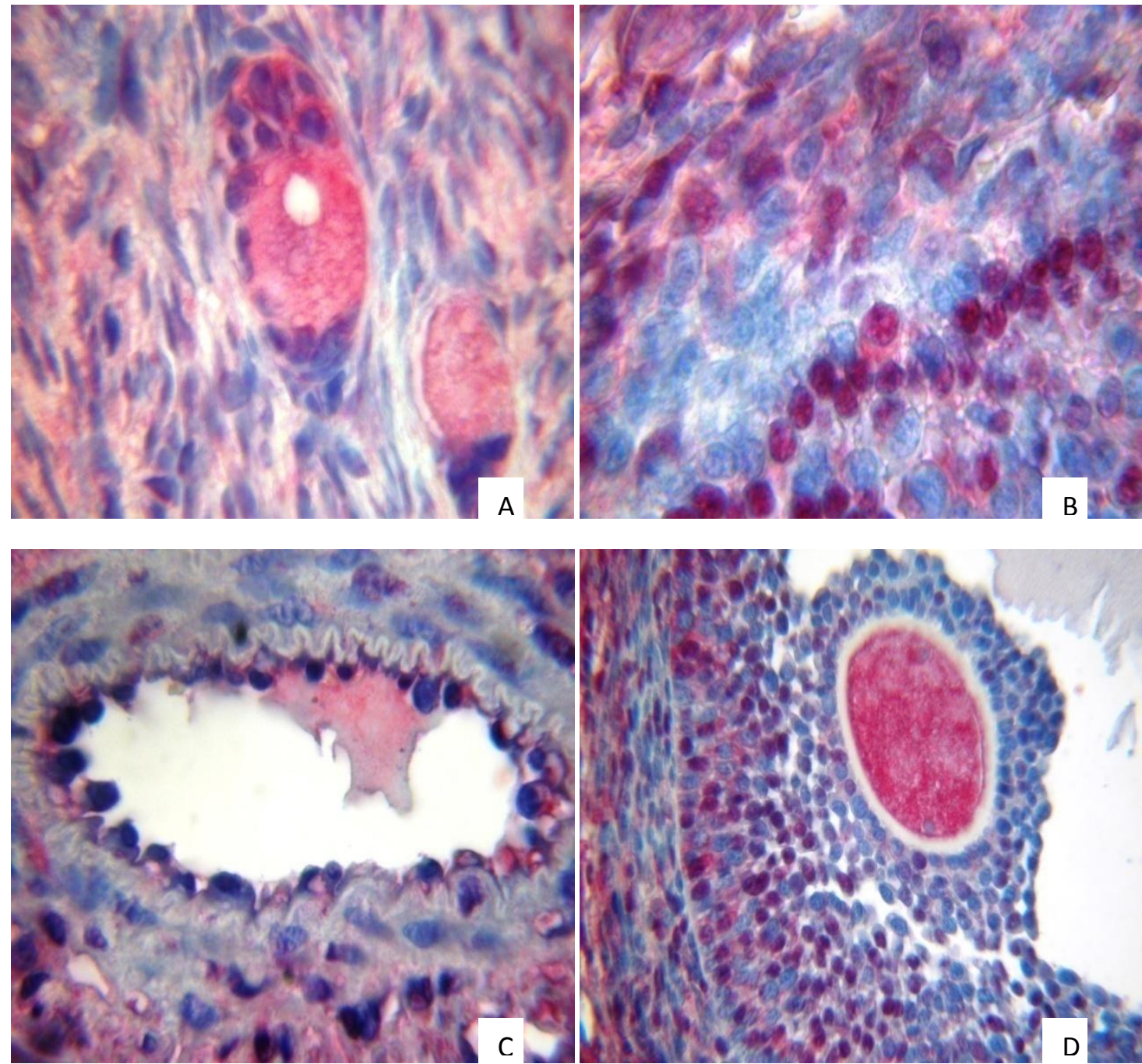

Fig. A. Microphotograph of ovarian tissue showing strong stain for $\mathrm{IL}-2^{+}$in the oocyte of primordial follicle. B. Microphotograph of ovarian section showing strong stain of IL $-2^{+}$cells in both granulosa and thecal cells of the follicle. C. Microphotograph of Immunohistochemical localization showing very weak stain for $\mathrm{IL}-2^{+}$cells in the blood capillary. D. Microphotograph of ovarian section showing weak stain in cumulus cells around the atretic oocyte.

Table 1: Frequency distribution of IL-2 ${ }^{+}$cells in cellular components of normal and atretic follicles.

\begin{tabular}{|c|c|c|c|c|c|c|c|c|}
\hline \multirow{2}{*}{$\begin{array}{l}\text { OVARIAN } \\
\text { COMPONEN } \\
\text { TS }\end{array}$} & \multicolumn{2}{|c|}{$\begin{array}{l}\text { PRIMORDIAL } \\
\text { FOLLICLES }\end{array}$} & \multicolumn{2}{|c|}{$\begin{array}{l}\text { PRIMARY } \\
\text { FOLLICLES }\end{array}$} & \multicolumn{2}{|c|}{$\begin{array}{l}\text { SECONDARY } \\
\text { FOLLICLES }\end{array}$} & \multicolumn{2}{|c|}{$\begin{array}{l}\text { DOMINANT } \\
\text { FOLLICLES } \\
\end{array}$} \\
\hline & $\begin{array}{l}\text { NORMA } \\
\mathrm{L}\end{array}$ & $\begin{array}{l}\text { ATRETI } \\
\mathrm{C}\end{array}$ & $\begin{array}{l}\text { NORMA } \\
\mathrm{L}\end{array}$ & $\begin{array}{l}\text { ATRETI } \\
\mathrm{C}\end{array}$ & $\begin{array}{l}\text { NORMA } \\
\mathrm{L}\end{array}$ & $\begin{array}{l}\text { ATRETI } \\
\mathrm{C}\end{array}$ & $\begin{array}{l}\text { NORMA } \\
\mathrm{L}\end{array}$ & $\begin{array}{l}\text { ATRETI } \\
\mathrm{C}\end{array}$ \\
\hline $\begin{array}{l}\text { GRANULOS } \\
\text { A CELLS }\end{array}$ & - & - & + & - & + & ++ & ++ & ++++ \\
\hline $\begin{array}{l}\text { THECAL } \\
\text { CELLS }\end{array}$ & - & - & - & - & + & ++ & +++ & ++++ \\
\hline OOCYTES & ++ & - & ++ & - & +++ & ++++ & ++++ & ++++++ \\
\hline $\begin{array}{l}\text { CUMULUS } \\
\text { OOPHORUS }\end{array}$ & - & - & - & - & + & ++ & + & +++ \\
\hline
\end{tabular}


Key to observation: negative $(-)$, weakly $(+)$, mild $(++)$, moderate $(+++)$, strong $(++++)$, intense $(+++++)$ indicate the relative intensities of the signals average for the specimens during follicular development.

\section{DISCUSSION}

Immunohistochemical localization has revealed that the number of IL- $2^{+}$cells was higher in the large-sized $(\geq 8 \mathrm{~mm}$ ) atretic follicles as compared to the normal follicles of the same size. The present observation strongly endorse that the goat ovary is the site of production of ILs and their receptors as has already been demonstrated in both granulosa and theca cells, whilst maximal production occurs in preovulatory follicle after gonadotropin action $[18,19]$. The ILs has several sites of synthesis in the ovary. The role of ILs in local processes is still poorly known, although there is evidence for its ability to stimulate ovarian cell proliferation, suppress apoptosis, and therefore to promote ovarian follicular growth. Although during present study no significant change in IL-2 reactivity was observed in corpora lutea of different categories in goat. However in humans a significant number of $\mathrm{T}$ cells in the corpus luteum where activated $\mathrm{T}$ cells were detected by an antiIL-2 receptor antibody and these cells corresponded with T4 cells in that area. This indicated that there are functional $\mathrm{T}$ cells in the human corpus luteum with IL-2 receptors permitting the possible effect of IL-2 on cells of the corpus luteum. Small groups of T cells were frequently observed near the capillaries of the theca-luteal area, indicating that these cells may migrate from the blood vessels into the substance of the corpus luteum. One of the most important functions of the T4 cells is to help the B cell respond to protein antigen [20].

In conclusion, it was observed that the number of IL-2 $2^{+}$cells increased in the atretic follicles, and they probably contribute to the tissue regression of follicles by stimulating macrophages and enhancing the death of follicular cells. The ovary is in a constant state of development, breakdown, and repair. These events take place simultaneously at sites of follicles and corpora lutea. Present data support the hypothesis that leukocyte populations are involved in these processes and provide an anatomical basis for immunoendocrine interactions within the normal goat ovary. The results of the present study indicate that various immune cells, particularly lymphocytes, differentially migrate into, and out of the goat corpus luteum. The temporal nature of this migration indicates involvement of certain populations of these cells in modulation of luteal activity. Further studies are required to identify specific products of these cells that are present throughout the life of the corpus luteum to clarify the role of immune cells within this tissue.

\section{ACKNOWLEDGEMENTS}

The authors acknowledge University Grants Commission, New Delhi for financial support and also thankful to Kurukshetra University, Kurukshetra for the laboratory facilities.

\section{REFERENCES}

[1]. M. Brannstrom, and R.J. Norman, Involvement of leukocytes and cytokines in the ovulatory process and corpus luteum function, Hum. Reprod., 8, 1993, 1762-1775.

[2]. P.F. Terranova, and V.M. Rice, Review: cytokine involvement in ovarian processes, Am. J. Reprod. Immunol., 37, 1997, 50-63.

[3]. O. Bukulmez, and A. Arici, Leukocytes in ovarian function, Hum. Reprod., 6, 2000, 1-15.

[4]. Saito S. 2001. Cytokine cross- talk between mother and the embryo-placenta, J. Reprod. Immunol., 52, 2001, 15-33.

[5]. B.C. Paria, J. Reese, S.K. Das, and S.K. Dey, Deciphering the cross-talk of implantation: advances and challenges, Sci., 296, 2002, 2185-2188.

[6]. S. Schafer-Somi, Cytokine during early pregnancy of mammals: a review, Am. Reprod. Sc., 75, 2003, 73-94.

[7]. D.H. Townson, and A.R. Liptak, Chemokines in the corpus luteum: Implications of leukocyte chemotaxis, Reprod. Biol. Endocrinol., 1, 2003, 94.

[8]. A. Moffett, and C. Loke, Immunology of placentation in eutherian mammals, Nature reviews. Immunology., 6, 2006, 584-594.

[9]. G. Chaouat, S. Dubanchet, and N. Ledee, Cytokines: important for implantation, J. Ass. Reprod. Gen., 24, 2007, 491-505.

[10]. D.A. Morgan, F.W. Ruscetti, and R.C. Gallo, Purification of normal human T-cell growth, Sci., 193, 1976, 1007-1008.

[11]. J.M. Zarling, and F.H. Bach, Continuous culture of T cells cytotoxic for autologous human leukaemia cells, Nature., 280, 1979, 685-688. 
[12]. S. Gillis, K.A. Smith, and J. Watson, Biochemical characterization of lymphocyte regulatory molecules, J. Immunol., 124, 1980, 1954-1962.

[13]. C.S. Henney, K. Kuribayashi, D.E. Kern, and S. Gillis, 1981. Interleukin-2 augments natural killer cell activity, Nature., 291, 1981, 335-338.

[14]. J.R. Ortaldo, A.T. Mason, J.P. Gerard, L.E. Henderson, W. Farrar, R.F. Hopkins, R.B. Herberman, and H. Rabin, Effects of natural and recombinant IL 2 on regulation of IFN gamma production and natural killer activity: lack of involvement of the Tac antigen for these immunoregulatory effects, J. Immunol., 133, 1984, 179-183.

[15]. M.C. Mingari, F. Gerosa G. Carra, R.S. Accolla, A. Moretto, R.H. Zubler, T.A. Waldmann, and L. Moretta, 1984. Human interleukin-2 promotes proliferation of activated B cells via surface receptors similar to those of activated T cells, Nature., 312, 1984, 641-643.

[16]. E.A. Grimm, A. Mazumder, H.Z. Zhang, and S.A. Rosenberg, Interleukin-2-activated autologous human peripheral blood lymphocytes, J. Exp. Med., 155, 1982, 1823-1841.

[17]. A. Mazumder, and S.A. Rosenberg, Successful immunotherapy of natural killerresistant established pulmonary melanoma, J. Exp. Med., 159, 1984, 495-507.

[18]. M. Brannstrom, Potential role of cytokines in ovarian physiology: the case for interleukin-1. In: The Ovary. 2nd (Ed). Amsterdam: Leung PCK, Adash EY. Elsevier-Academic Press, 2004, 261-71.

[19]. W.V. Ingman, and R.L. Jones, R. Cytokine knockouts in reproduction: the use of gene ablation to dissect roles of cytokines in reproductive biology, Hum. Reprod., 14, 2008, 179-92.

[20]. Y. Wang, J.E. Nesbitt, N.L. Fuentes, and G.M. Fuller, Molecular cloning and characterization of the rat liver IL-6 signal transducing molecule, gp130, Geno., 14, 1992, 666-672. 